\title{
The Membrane-Bound Intestinal Enzymes of Waxwings and Thrushes: Adaptive and Functional Implications of Patterns of Enzyme Activity
}

\author{
Mark C. Witmer ${ }^{*}$ \\ Carlos Martínez del Rio \\ Department of Zoology and Physiology, University of \\ Wyoming, Laramie, Wyoming 82071
}

Accepted 4/2/01

\begin{abstract}
Cedar waxwings (Bombycilla cedrorum) feed predominantly on fruits that are rich in simple sugars and low in nitrogen, supplementing this diet with arthropod prey during the summer months as well as flowers and tree sap in springtime. In contrast, thrushes feed extensively on fatty, protein-rich invertebrate prey, supplemented with sugary and lipid-rich fruits. Simple sugars and fats are digested and/or absorbed by distinctly different physiological mechanisms, which suggests the possibility of contrasting digestive strategies in animals specialized to diets containing one of these two energy sources. In this study, we quantified enzymatic activity of three membranebound intestinal enzymes of cedar waxwings and five species of thrushes to explore this aspect of their digestive physiology. These enzymes catalyze the final steps in the digestion of carbohydrates (sucrase-isomaltase and maltase-glucoamylase) and protein (aminopeptidase-N). The two carbohydrases are homologous enzymes with overlapping functions; both enzymes catalyze the hydrolysis of maltase and isomaltase. The membrane-bound digestive enzyme systems that we described for cedar waxwings and thrushes can be explained by the particular nutrients contained within their respective natural diets. Consistent with previous work, cedar waxwings displayed intestinal sucrase activity, whereas thrushes did not. Correspondingly, cedar waxwings eat some foods containing sucrose, whereas thrushes do not. Sucrase-isomaltase conferred all maltase and isomaltase activity in cedar waxwings. In contrast, all maltase and isomaltase activity in thrushes was necessarily sucrase independent, which indicated the presence of maltase-
\end{abstract}

${ }^{\star}$ Corresponding author. Present address: Department of Biology, Bryn Mawr College, Bryn Mawr, Pennsylvania 19010; e-mail: mwitmer@brynmawr.edu.

Physiological and Biochemical Zoology 74(4):584-593. 2001. (C) 2001 by The University of Chicago. All rights reserved. 1522-2152/2001/7404-99133\$03.00 glucoamylase. The absence of sucrase-independent maltase activity in cedar waxwings suggests that sucrase-isomaltase obviates the need for maltase-glucoamylase. Indeed, total maltase and isomaltase activities were much higher in cedar waxwings than in thrushes. Neither waxwings nor thrushes eat starchy foods; sucrase-isomaltase in waxwings and maltaseglucoamylase in thrushes probably function in digesting glycogen in animal foods. We suggest that digestive traits associated with specialization to monosaccharide-rich fruits (lack of a grinding gizzard) by frugivorous waxwings and thrushes may prevent utilization of starchy seeds. Total aminopeptidase$\mathrm{N}$ activity in cedar waxwings was indistinguishable from the allometric pattern among thrush species, but the distribution of this enzyme along the intestines of waxwings and thrushes was distinctly different, which demonstrates that total enzyme activity can be insufficient as a descriptor of the functional activity of brush border enzymes. Aminopeptidase-N activity peaked in the anterior part of the intestines of thrushes and in the terminal portion of the intestines of waxwings, which suggests contrasting strategies for protein digestion from fatty versus sugary diets, respectively.

\section{Introduction}

Cedar waxwings (Bombycilla cedrorum) and thrushes show contrasting digestive strategies associated with specialization to sugary fruits and fatty, protein-rich invertebrates, respectively (Witmer 1996, 1998; Witmer and Van Soest 1998). Sugary fruits eaten by waxwings contain the simple sugars glucose and fructose, nutrients that are readily absorbed by active and passive mechanisms without enzymatic breakdown (Pappenheimer and Reiss 1987). During a brief period in the spring, cedar waxwings also regularly eat some foods that contain sucrose (plant sap, buds, flowers, scale insects; Witmer 1996). Thrushes, in contrast, consume predominantly arthropod prey, supplemented with both sugary (glucose and fructose) and fatty fruits throughout the year (Martin et al. 1951; Wheelwright 1986; Witmer 1996). Arthropods are typically rich in protein, fat, and glycogen (Redford and Dorea 1984; Bell 1990).

Carbohydrates and proteins are required on a daily basis by birds (Robbins 1993). Complex carbohydrates and proteins are broken down by a sequence of enzymatic reactions into their 
constituent monomers before absorption (Alpers 1987; Stevens 1988; Karasov and Hume 1997). Starch and glycogen are initially cleaved into oligosaccharides by amylases secreted by the salivary glands and pancreas. Proteins are initially digested by the hydrolytic action of stomach acid and pepsin and then sequentially broken down by pancreatic proteases into successively smaller peptides. Enzymes bound to the intestinal mucosa catalyze the final breakdown of oligosaccharides and oligopeptides to simple sugars and amino acids or oligopeptides, respectively (Alpers 1987). Because complex carbohydrates and proteins cannot be absorbed until they are broken down into their constituent monomers (or oligopeptides), the hydrolytic capacities of membrane-bound enzymes provide a measure of the ability of animals to utilize complex carbohydrates and protein. Thus, membrane-bound hydrolases represent potentially important traits to characterize animal digestive strategies.

Sucrase-isomaltase catalyzes the hydrolysis of sucrose $(\alpha 1$ $2 \beta$ glucose, fructose) into its constituent sugars. This dimeric enzyme also catalyzes the hydrolysis of maltose ( $\alpha$ 1-4 glucose, glucose) and isomaltose ( $\alpha$ 1-6 glucose, glucose), disaccharides that are derived from the digestive breakdown of starch and glycogen. Maltose and isomaltose are also hydrolyzed by a specific maltase-glucoamylase complex, which does not have sucrase activity (Alpers 1987; Martínez del Rio 1990; Martínez del Rio et al. 1995). Physiological studies with laboratory mammals implicate aminopeptidase-N (also known as leucineaminopeptidase or amino-oligopeptidase) as the primary exopeptidase of the brush border membrane, cleaving $\mathrm{NH}_{2}$ terminal residues from oligopeptides to yield dipeptides and amino acids for absorption (Maroux et al. 1973; Kania et al. 1977; Martínez del Rio et al. 1995).

Cedar waxwings possess sucrase-isomaltase (Martínez del Rio et al. 1989; McWilliams et al. 1999). In contrast, three thrush species studied to date do not show physiologically significant levels of sucrase activity but do show maltase activity, which indicates the presence of maltase-glucoamylase (Catharus aurantiirostris and Turdus rufopalliatus, Martínez del Rio 1990; Turdus migratorius, Karasov and Levey 1990). Martínez del Rio (1990) suggested that birds without sucrase-isomaltase may be ineffective in hydrolyzing maltose, but this hypothesis begs the question of the functional significance of maltase-glucoamylase. Sucrase-isomaltase and maltase-glucoamylase are homologous enzymes that are functionally redundant in catalyzing the hydrolysis of maltose and isomaltose (Nichols et al. 1998). Comparing these carbohydrases in waxwings and thrushes should provide insights into the evolution and functioning of these enzyme systems in fruit-eating birds. For example, does sucrase-isomaltase in cedar waxwings eliminate the need for maltase-glucoamylase in this species? The presence of maltaseglucoamylase in waxwings would suggest either that this enzyme provides supplemental maltase activity to sucraseisomaltase or that maltase-glucoamylase functions somewhat differently than sucrase-isomaltase in digesting glycogen.
Aminopeptidase- $\mathrm{N}$ has been reported in the cedar waxwing (McWilliams et al. 1999), but there are no comparable data for thrushes. If total activity of an intestinal enzyme is directly related to the quantity of its substrate in an animal's natural diet, the relatively low protein content of the diet of the cedar waxwing (Witmer 1996) would predict relatively low aminopeptidase- $\mathrm{N}$ activity for this species.

We compared total hydrolytic activity of sucrase-isomaltase, maltase-glucoamylase, and aminopeptidase- $\mathrm{N}$, as well as the distribution of enzyme activities throughout the intestines of cedar waxwings and five species of thrushes. We undertook this work as an exploratory, descriptive study of this facet of the digestive physiology of two groups of fruit-eating birds that differ in the nutrient composition of their natural diets. By comparing cedar waxwings to thrushes varying in body size, we were able to make quantitative comparisons that controlled for effects due to body size. We depict enzyme activity as a function of body size, comparing values for cedar waxwings to the regression that describes the allometric relationship among thrush species. Because phylogenetic relatedness confounds the use of species as units of replication, we also compared enzyme activity in cedar waxwings to other members of the Muscicapoidea, the monophyletic clade that includes both cedar waxwings and thrushes, using phylogenetically independent contrasts (Felsenstein 1985). We make inferences about the adaptive and functional significance of patterns of intestinal enzyme activity in waxwings and thrushes.

\section{Material and Methods}

We compared the activities of three membrane-bound enzymes (sucrase-isomaltase, maltase-glucoamylase, and aminopeptidase-N) in cedar waxwings $(n=4)$ to those in five species of thrushes (American robin, Turdus migratorius, $n=3$; wood thrush, Hylocichla mustelina, $n=3$; hermit thrush, Catharus guttatus, $n=1$; gray-cheeked thrush, Catharus minimus, $n=$ 1 ; and Swainson's thrush, Catharus ustulatus, $n=1$ ). Birds were captured near Ithaca, New York, and maintained in captivity for more than $2 \mathrm{yr}$ before this study. The maintenance diet was moistened Eukanuba Small Bites puppy chow (Iams, Dayton, Ohio) supplemented with a variety of natural fruits. Bird diets were supplemented with crab apple fruits (Malus spp.) for the $4 \mathrm{~d}$ before tissue collection. We maintained birds under similar conditions of captivity and diet for an extended period to control for potentially confounding environmental influences on the activity of digestive enzymes in our comparative study. The quantitative expression of digestive enzymes can be modulated by dietary nutrient content (Afik et al. 1995; Martínez del Rio et al. 1995; Karasov and Hume 1997; Sabat et al. 1998; Levey et al. 1999).

For collection of gut tissues, birds were fasted overnight, killed with an isofluorane overdose, and their intestines were immediately excised and placed in ice-cold $1.02 \%$ saline. At 
least three, but up to 11 , samples of intestinal tissue approximately $1 \mathrm{~cm}$ in length were taken throughout the intestine, slit longitudinally to open the gut tube. For two individuals (cedar waxwing and wood thrush), the entire intestine was sampled. Position of each section (distance from pylorus) and the length and width of each intestinal segment were recorded to calculate intestinal surface area (nominal area). Tissues were rinsed with clean ice-cold saline, blotted, weighed, and stored in liquid $\mathrm{N}_{2}$.

Tissue samples were prepared for enzyme analysis by thawing at $4^{\circ} \mathrm{C}$ and homogenizing in $350 \mathrm{mM}$ mannitol in $1 \mathrm{mM}$ Hepes/ $\mathrm{KOH}, \mathrm{pH} 7.5$, for $30 \mathrm{~s}$ in an OMNI 5000 homogenizer at setting 6. Disaccharidase activities were measured by the rate at which stock solutions of each sugar substrate (sucrose, maltose, isomaltose) incubated with tissue homogenates yielded glucose. We refer to rates of maltose and isomaltose hydrolysis as maltase and isomaltase activity, respectively, regardless of the enzyme(s) responsible for catalytic activity (sucrase-isomaltase and maltase-glucoamylase). Glucose concentrations of incubated solutions were assayed colorimetrically using Glucose-Trinder 500 reagent (Sigma Chemical). These methods are modified from Dahlqvist (1984), as described in Martínez del Rio (1990) and Martínez del Rio et al. (1995). Tissue homogenates $(100 \mu \mathrm{L})$ were incubated at $40^{\circ} \mathrm{C}$ (Prinzinger et al. 1991) with $100 \mu \mathrm{L}$ of $56 \mathrm{mM}$ sugar solutions in $0.1 \mathrm{M}$ maleate/ $\mathrm{NaOH}$ buffer, $\mathrm{pH}$ 6.5 , for $10 \mathrm{~min}$. Reactions were then arrested by adding $3 \mathrm{~mL}$ of the Glucose-Trinder stop/develop reagent, and absorbance was measured at $505 \mathrm{~nm}$.

We used L-alanine-p-nitroanilide as a substrate for aminopeptidase-N. Hydrolysis of the peptide bond yields alanine and $p$-nitroaniline; the concentration of the latter reaction product was determined colorimetrically at $384 \mathrm{~nm}$. We added $10 \mu \mathrm{L}$ of homogenate to $1 \mathrm{~mL}$ of assay $\operatorname{mix}(2.0 \mathrm{mM} \mathrm{L}$-alanine- $p$ nitroanilide in $0.2 \mathrm{M} \mathrm{NaH} \mathrm{PO}_{4} / \mathrm{Na}_{2} \mathrm{HPO}_{4}$ buffer, $\mathrm{pH} 7.0$ ), incubated this solution at $40^{\circ} \mathrm{C}$ for $10 \mathrm{~min}$, and arrested the reaction with $3 \mathrm{~mL}$ of ice-cold $2 \mathrm{~N}$ acetic acid. See Martínez del Rio (1990) and Martínez del Rio et al. (1995) for justification of the use of intestine homogenates and reaction rates relative to $\mathrm{V}_{\max }$ under these assay conditions. We measured the $\mathrm{pH}$ optima for each enzyme to validate our assay protocol (M. C. Witmer and C. Martínez del Rio, unpublished data); $\mathrm{pH}$ optima for these enzymes in cedar waxwings are reported in McWilliams et al. (1999).

Enzyme activities were standardized to nominal area of the intestine (Martínez del Rio 1990; Martínez del Rio et al. 1995). We statistically evaluated enzyme activity as a function of intestinal position by repeated-measures ANOVA, with bird species as a factor. For this analysis, we grouped the three Catharus spp. thrushes together, comparing among genera. Total (summed) enzyme activity for each bird was calculated by adding the activities of assayed gut sections and extrapolating activities over segments that were not included in enzyme assays. We assumed linear changes in enzyme activity between measured segments, approximating the pattern that we found for two individuals for whom we examined the entire intestine (cedar waxwing and wood thrush; Figs. 1, 2). We compared total maltase activity and aminopeptidase- $\mathrm{N}$ activity in cedar waxwings to the allometric patterns that we report among the five thrush species. We computed phylogenetically independent contrasts with the Macintosh program of Purvis and Rambaut

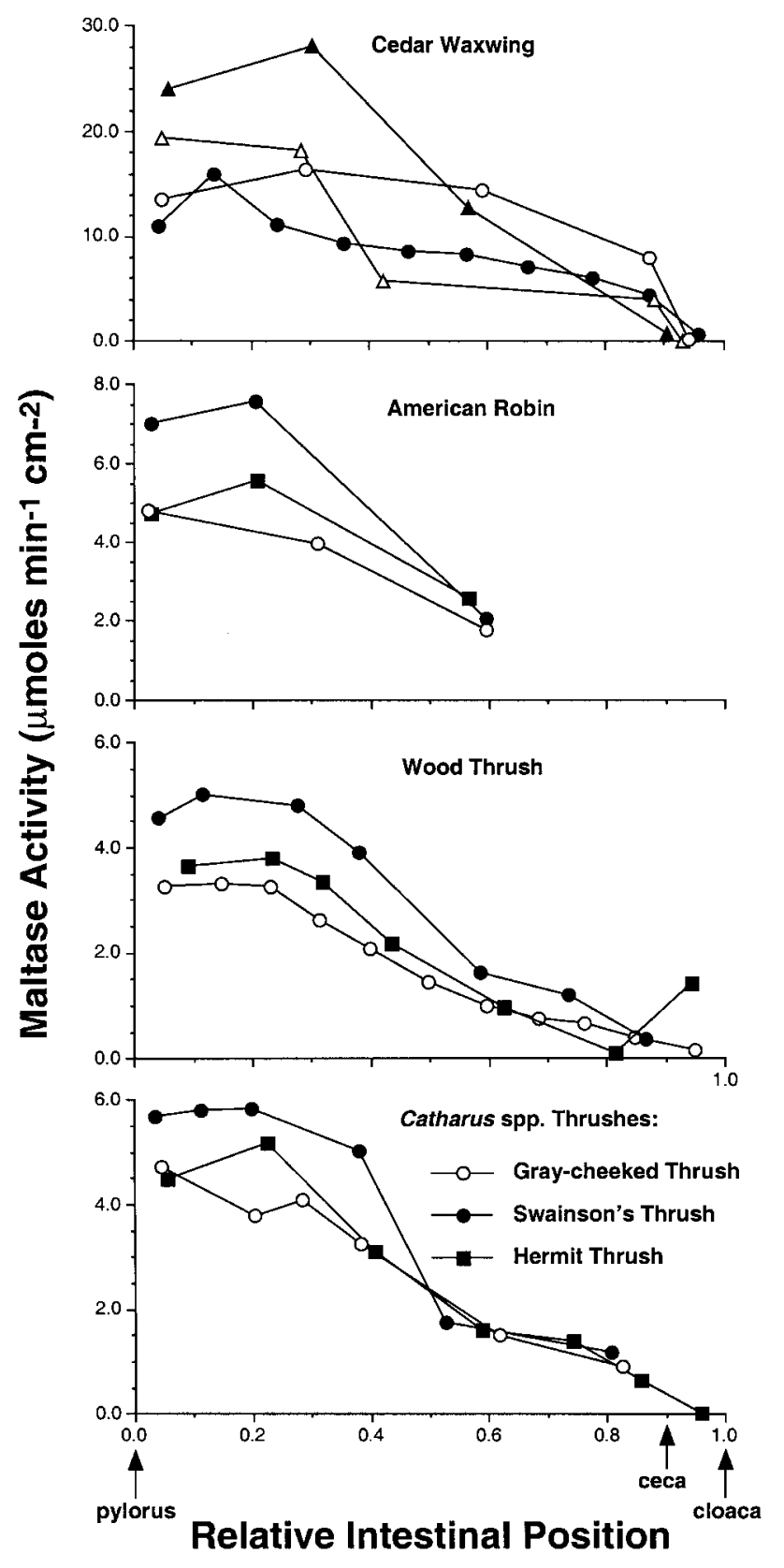

Figure 1. Maltase activity along the intestines of cedar waxwings and thrushes. Carbohydrase activity peaked proximally and declined distally along the intestines of all species. 


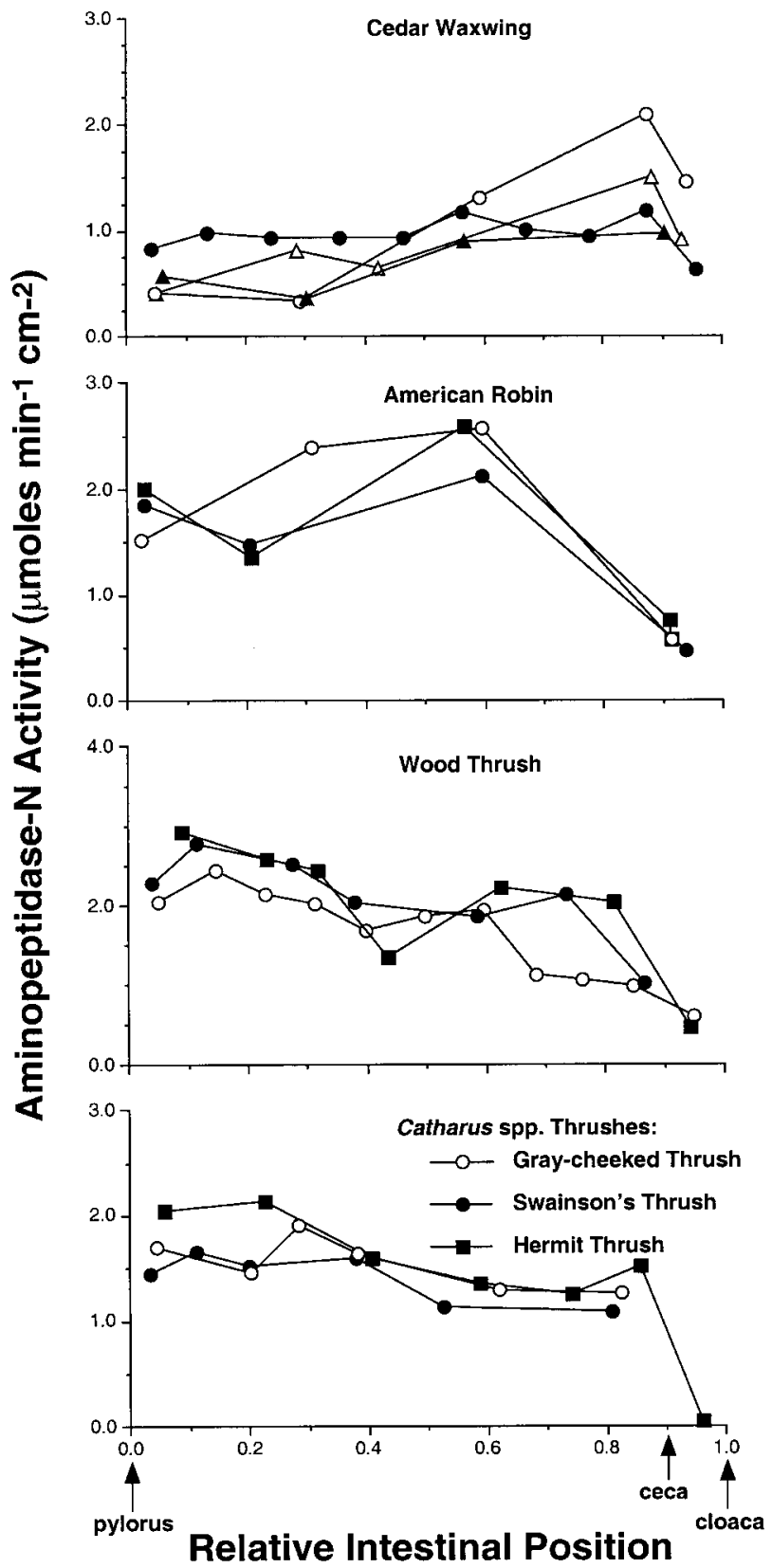

Figure 2. Aminopeptidase-N activity along the intestines of cedar waxwings and thrushes. In contrast to the pattern in thrushes, activity of this enzyme peaked in the distal intestine of cedar waxwings.

(1995) to evaluate whether enzyme activity in cedar waxwings differs from the allometric pattern among other members of the Muscicapoidea, including data for European starlings (Sturnus vulgaris) and gray catbirds (Dumetella carolinensis) from Martínez del Rio et al. (1995). The phylogeny and branch lengths used to structure and standardize our contrasts, re- spectively (Garland and Adolph 1994), were estimated from DNA hybridization (Sibley and Ahlquist 1990). For cedar waxwings, the only species that showed significant sucrase activity, we evaluated maltose and isomaltose hydrolysis capacity as a function of sucrase activity of individual intestinal segments by regressing hydrolysis rates of these two disaccharides against sucrase activity (Martínez del Rio 1990). We used ANCOVA, with individual bird as a factor, to evaluate how maltase and isomaltase hydrolysis changed as a function of sucrase activity.

\section{Results}

Patterns of Hydrolase Activity along the Intestine

Enzyme activities for the single individuals of each of the three Catharus spp. thrushes were very similar. Variation among these individuals was no greater than interindividual variation within the other three bird species that we examined (Figs. 1-3). Thus, we suspect that the Catharus spp. thrushes are similar in intestinal enzyme activity and that our data for these three individuals are reasonable approximations of the mean values of these measurements for these species under our experimental conditions.

Hydrolysis rates of carbohydrates (illustrated by maltase activity) in both cedar waxwings and thrushes peaked in the anterior intestine and declined toward zero activity in the posterior intestine (repeated-measures ANOVA, using data for the three anterior tissue samples: $F_{2,18}=11.6, P<0.001$; Fig. 1). This is a typical pattern for intestinal membrane-bound enzymes (Alpers 1987; Biviano et al. 1993; Martínez del Rio et al. 1995). Cedar waxwings showed maltase activity per unit nominal area of intestine approximately four times higher compared with the five thrush species (repeated-measures ANOVA: $F_{3,18}=13.9, P=0.001$; Fisher's protected least significant difference between Bombycilla and each of the thrush genera: $P<0.001$; Fig. 1).

The pattern of aminopeptidase- $\mathrm{N}$ activity along the intestine was strikingly different between cedar waxwings and thrushes (repeated-measures ANOVA, genus $\times$ gut position interaction: $F_{9,18}=8.2, P<0.001$; Fig. 2). For thrushes, aminopeptidase-N activity tended to decline distally. American robins showed a slightly different pattern than the other thrush species, with the highest aminopeptidase- $\mathrm{N}$ activity in the distal third of the small intestine. In contrast to the general pattern for all thrush species, aminopeptidase- $\mathrm{N}$ activity was highest in the terminal portion of the intestine of cedar waxwings, with relatively high enzyme activity in the distal ileum and proximal rectum. Our data are consistent with McWilliams et al.'s (1999) report that cedar waxwings showed comparable levels of aminopeptidase$\mathrm{N}$ activity in the posterior and anterior halves of the intestine. 


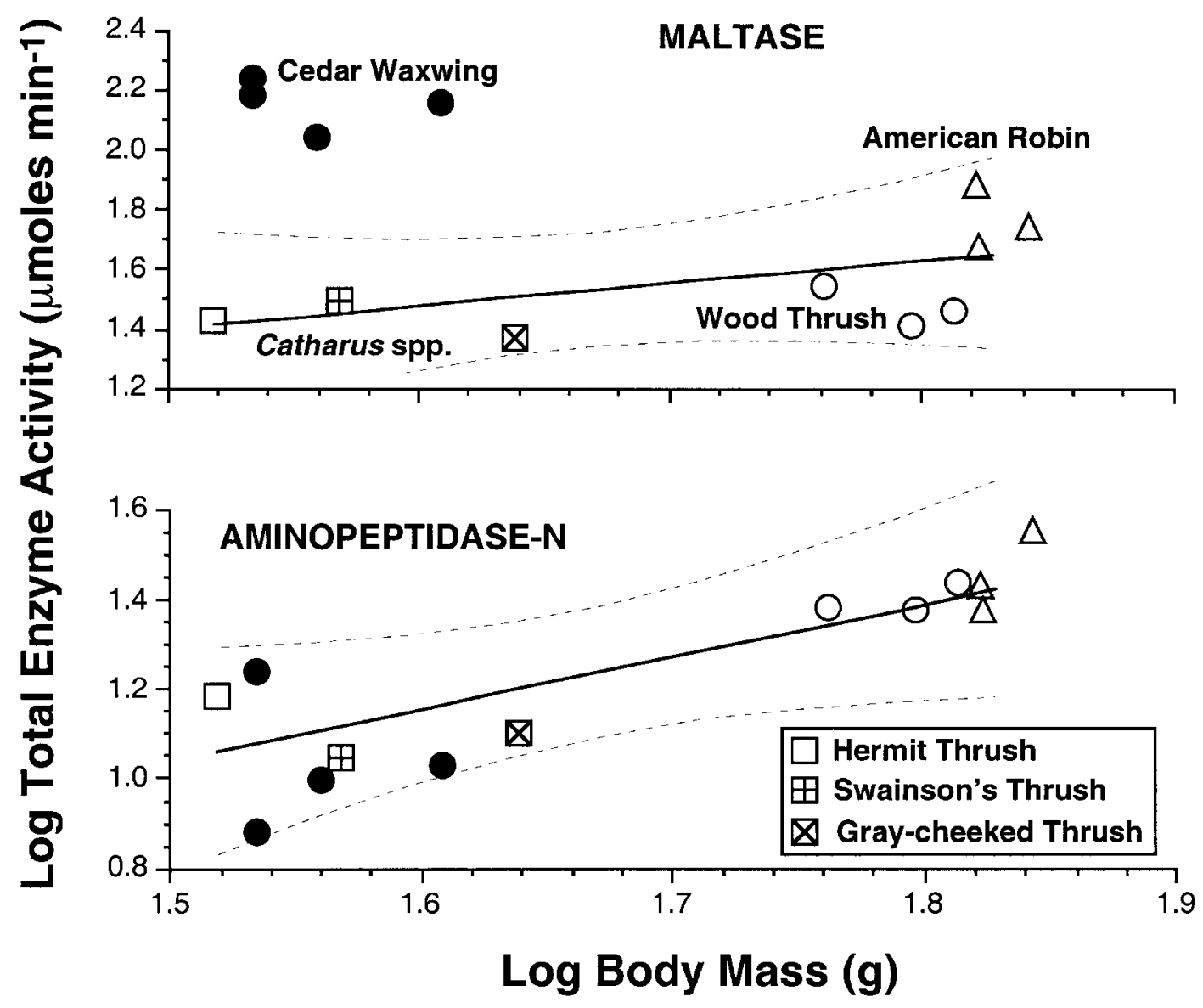

Figure 3. Enzyme activity as a function of body mass, comparing thrushes with cedar waxwings. Lines show least squares regressions for thrushes ( $\pm 95 \%$ confidence interval), using mean values for each species $(n=5)$. Total maltase activity for cedar waxwings was higher than the allometric relationship for thrushes, whereas total aminopeptidase-N activity for cedar waxwings was not different from the allometric pattern among thrushes.

\section{Comparisons of Total Enzyme Activity}

Cedar waxwings showed sucrase, maltase, and isomaltase activity, whereas thrushes showed very low levels of sucrase and isomaltase activity (Table 1). Total maltase activity in cedar waxwings was higher than the allometric relationship among thrush species (approximately fourfold), whereas total aminopeptidase- $\mathrm{N}$ activity in cedar waxwings was similar to the allometric pattern among thrush species (Table 1; Fig. 3). The independent contrasts of total enzyme activity against body mass (Fig. 4) corroborated our preceding results for the traditional allometric comparisons. Maltase activity for the Bombycillidae versus Muscicapidae/Sturnidae contrast was significantly different from the other Muscicapoidea contrasts (the maltase contrast involving the Bombycillidae was negative because, by the convention of the program, the values for the clade with the smaller value for the independent variable [body mass] are subtracted from the corresponding values for the clade with the larger value for the independent variable). The contrast of aminopeptidase- $\mathrm{N}$ activity against body mass for cedar waxwings was indistinguishable from the pattern among other Muscicapoidea standardized contrasts.

Because thrushes lacked sucrase-isomaltase, maltose and isomaltose hydrolysis was necessarily sucrase independent, which indicates the presence of maltase-glucoamylase (Table 1). For cedar waxwings, we estimated sucrase-independent maltase/isomaltase activity from the $y$-intercept of the regression of maltase/ isomaltase activity on sucrase activity (Martínez del Rio 1990). The relationship between both maltase and isomaltase activity and sucrase activity of individual intestinal segments did not differ among individual waxwings (ANCOVA, bird $\times$ enzyme activity interaction: maltase $F_{3,16}=0.85, P=0.49$; isomaltase $\left.F_{3,16}=1.39, P=0.28\right)$ and showed a tight positive relationship (ANCOVA: maltase $F_{1,16}=391.2, P<0.001$; isomaltase $F_{1,16}=$ 675.5, $P<0.001$; Fig. 5). The $y$-intercepts for both regressions 
Table 1: Body masses and total intestinal enzyme activities for cedar waxwings and thrushes (mean \pm 1 SD)

\begin{tabular}{|c|c|c|c|c|c|}
\hline \multirow[b]{2}{*}{ Species } & \multirow[b]{2}{*}{ Mass (g) } & \multicolumn{4}{|c|}{ Total Enzyme Activity $\left(\mu \mathrm{mol} \min ^{-1}\right)$} \\
\hline & & Sucrase & Maltase & Isomaltase & Aminopeptidase- $\mathrm{N}$ \\
\hline Bombycilla cedrorum $(n=4)$ & $36.3 \pm 3.0$ & $20.2 \pm 2.3$ & $145.3 \pm 26.9$ & $26.0 \pm 3.4$ & $11.4 \pm 4.2$ \\
\hline Catharus minimus $(n=1)$ & 43.5 & .2 & 23.6 & 1.9 & 12.7 \\
\hline Catharus guttatus $(n=1)$ & 33.0 & .2 & 26.9 & .7 & 15.3 \\
\hline Catharus ustulatus $(n=1)$ & 37.0 & .05 & 31.1 & .8 & 11.2 \\
\hline Hylocichla mustelina $(n=3)$ & $61.8 \pm 3.7$ & $.3 \pm$ & $29.9 \pm 4.6$ & $.6 \pm .3$ & $25.2 \pm 2.0$ \\
\hline Turdus migatorius $(n=3)$ & $67.5 \pm 1.9$ & $.4 \pm$ & $60.0 \pm 15.2$ & $9.1 \pm 9.9$ & $29.0 \pm 6.2$ \\
\hline
\end{tabular}

were not significantly different from zero (Fig. 5), which suggests that maltase and isomaltase activities in cedar waxwings were due solely to the presence of sucrase-isomaltase.

\section{Discussion}

Our results corroborate previous work showing intestinal sucrase activity in cedar waxwings (Martínez del Rio et al. 1989; McWilliams et al. 1999) but not in thrushes (Karasov and Levey 1990; Martínez del Rio 1990). The presence of sucrase-isomaltase in cedar waxwings is probably associated with this species' regular seasonal consumption of foods containing sucrose, such as flowers, buds, sap, and scale insects (Witmer 1996 and references therein). Rufous-tailed plant cutters (Phytotoma rara), which ingest young leaves and shoots in addition to fruit, also exhibit high levels of sucrase-isomaltase (Meynard et al. 1999; López-Calleja and Bozinovic 2000). Unlike thrushes, cedar waxwings did not show sucrose-independent amylase activity that would indicate the presence of maltase-glucoamylase (Martínez del Rio 1990). This result conflicts with McWilliams et al.'s (1999) report that 29\%-39\% of maltase activity in cedar waxwings was sucrase independent, a discrepancy that calls for further study. Consistent with our result, the absence of sucraseindependent maltase activity has been reported for two other passerines, the frugivorous yellow-rumped warbler (Dendroica coronata; Afik et al. 1995) and the frugivorous/folivorous rufous-tailed plant cutter (Meynard et al. 1999). The presence of sucrase-isomaltase confers relatively high maltase and isomaltase activities in waxwings, which presumably eliminates the need for maltase-glucoamylase. Relatively high amylase activity in cedar waxwings, instead of representing a functional trait, may simply be a consequence of conserved functional similarity between sucrase-isomaltase and maltase-glucoamylase. These homologous enzymes share identical catalytic sites and are members of the same enzyme family (Nichols et al. 1998).

Thrushes showed only trace levels of sucrase activity, and these birds do not consume sucrose-rich foods. The traces of sucrase activity may be the result of minor microbial contamination of intestinal samples. In contrast to cedar waxwings, thrushes showed sucrose-independent maltase and isomaltase activities, which indicates the presence of maltase-glucoamylase.
Despite possessing intestinal enzymes that catalyze the final products of starch digestion in both cedar waxwings (sucraseisomaltase) and thrushes (maltase-glucoamylase), these frugivores do not eat starchy seeds. Intestinal amylase activity in these birds probably functions in digesting glycogen in the animal foods that they eat. We suggest that other features of their digestive systems associated with specialization to frugivory and seed dispersal may preclude the utilization of starchy seeds, like the absence of the powerful seed-grinding gizzard that is found in granivores (McLelland 1975).

Our results suggest that protein digestion is fundamentally different in cedar waxwings and thrushes. This may be a consequence of different strategies associated with digestion of protein from lipid- versus monosaccharide-rich diets. The distribution of aminopeptidase- $\mathrm{N}$ activity along the intestines of thrushes suggests that protein digestion takes place principally in the duodenum, where emulsification and digestion of fats typically occurs (Place 1992; Place and Stiles 1992). Relatively high aminopeptidase-N activity in the hindgut of cedar waxwings suggests that the final stages of protein digestion occur in the terminal portion of the intestine. A similar pattern of aminopeptidase- $\mathrm{N}$ activity along the intestine has been reported in the folivorous rufous-tailed plant cutter (Meynard et al. 1999), which suggests a common trait for birds specialized to sugary, low-protein foods. For sugary fruits that can be rapidly processed through the gut because simple sugars are readily absorbed, the distribution of aminopeptidase- $\mathrm{N}$ in cedar waxwings may maximize exposure of dietary protein to acid and enzymatic hydrolysis before the final stages of digestion and absorption. Meynard et al. (1999) proposed a similar hypothesis for rufous-tailed plant cutters. This trait may also enhance the ability of birds specialized to foods with a low nitrogen-tocarbohydrate ratio to recover precious nitrogen from digestive secretions and excretory products. The lower intestine of birds is an important site of water and electrolyte absorption (Skadhauge 1982; Thomas 1982; Anderson and Braun 1985), and for cedar waxwings, this terminal region appears to be important in nutrient digestion and absorption as well. In the distal ileum and proximal rectum of cedar waxwings, the villi become papillate (M. C. Witmer and D. McClearn, unpublished data), 

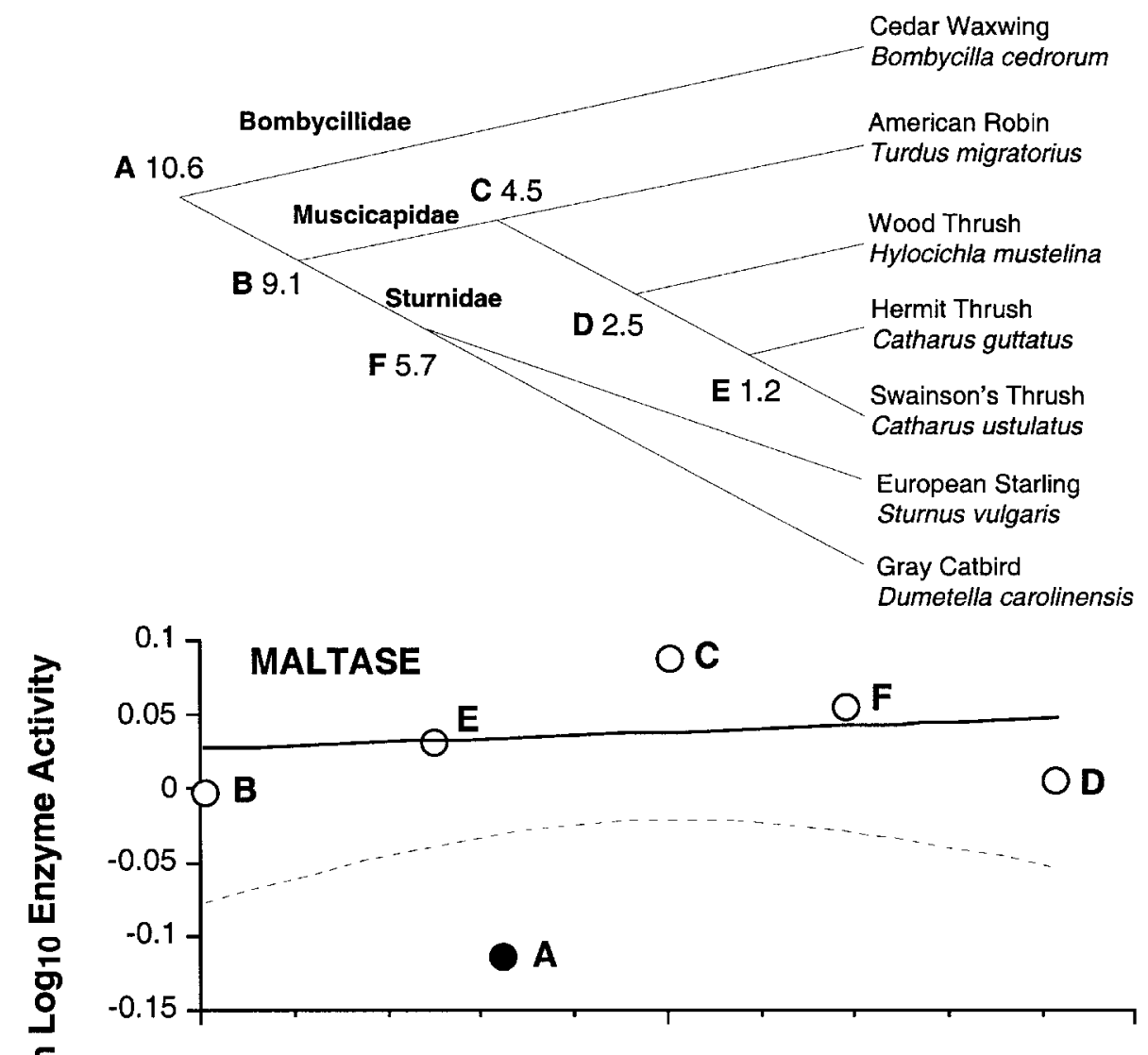

章

\subsection{AMINOPEPTIDASE-N}

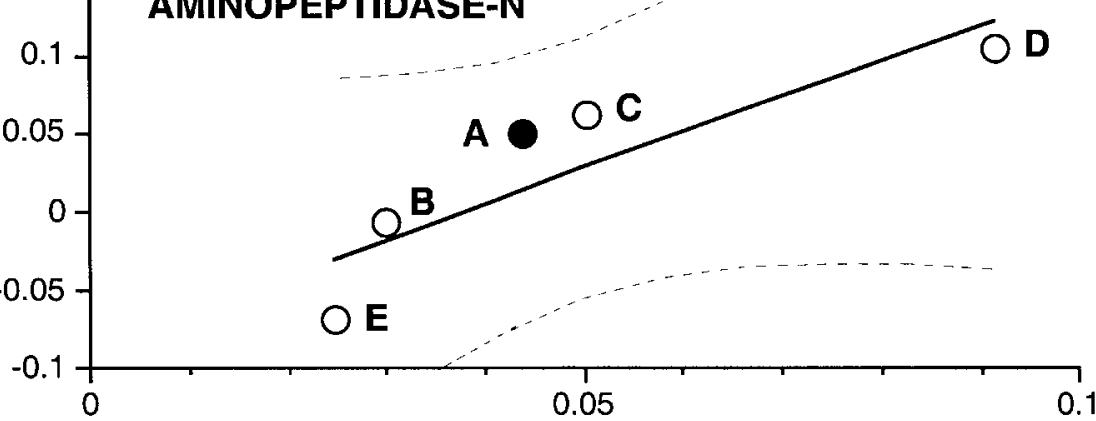

Standardized Contrast in $\log _{10}$ Body Mass

Figure 4. Phylogenetically independent contrasts of enzyme activity against body mass for cedar waxwings, four thrush species, gray catbirds (maltase only), and European starlings, closely related frugivores in the superfamily Muscicapoidea (Sibley and Ahlquist 1990). The phylogeny is from Sibley and Ahlquist's (1990) DNA-hybridization study, with nodes indicated by capital letters, followed by $\Delta \mathrm{T}_{50} \mathrm{H}$ values (the difference in melting temperatures of homoduplex and heteroduplex DNA hybrids). We used $\Delta \mathrm{T}_{50} \mathrm{H}$ values as estimates of evolutionary branch lengths to standardize our contrasts (Felsenstein 1985; Garland and Adolph 1994; Purvis and Rambaut 1995). Maltase activity was significantly different for the contrast including cedar waxwings compared with other Muscicapoidea contrasts, whereas the corresponding contrast for aminopeptidase$\mathrm{N}$ activity was indistinguishable from other Muscicapoidea contrasts. 


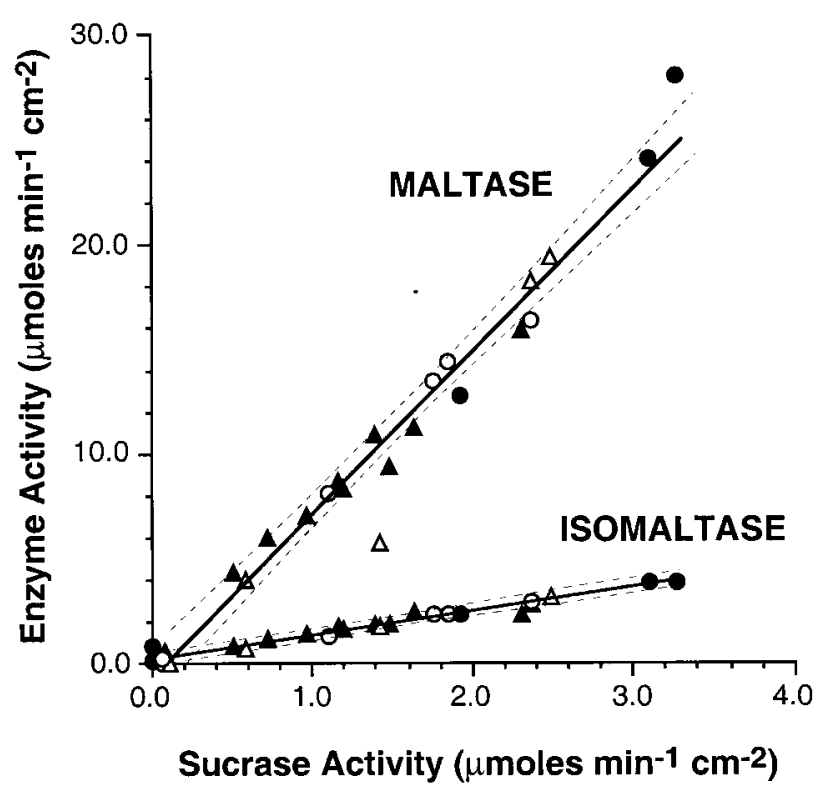

Figure 5. Maltase and isomaltase activities plotted against sucrase activity for cedar waxwing intestinal segments to estimate sucraseindependent hydrolysis of maltose and isomaltose. Symbols distinguish individual birds. Lines show least squares regressions ( $\pm 95 \%$ confidence interval) for all data. Both relationships intercept the origin, which suggests that hydrolysis of maltose and isomaltose in cedar waxwings is solely due to sucrase-isomaltase.

carrier-mediated glucose transport remains elevated, and the luminal contents are mixed by retroperistaltic refluxing (Levey and Duke 1992). These traits may be associated with digestive specialization to a diet rich in simple sugars.

Our finding that total aminopeptidase- $\mathrm{N}$ activity was the same for both cedar waxwings and thrushes did not support the prediction that proteinase activity would be correlated with the proportion of protein-rich animal foods in a species' overall diet. This result may be partly a consequence of the fact that the scale at which digestive systems operate is the nutrient mixture of gut contents rather than the overall diet. Indeed, the guts of fruit-eating birds tend to contain single food types that reflect their most recent meal (fruit or animal foods; Witmer 1996; C. Martínez del Rio and S. Helmy, unpublished data). Furthermore, our results showing different patterns of aminopeptidase- $\mathrm{N}$ activity along the intestines of waxwings and thrushes, but similar levels of total enzyme activity, suggest that total enzyme activity can be insufficient in describing functional differences in the digestive enzymes of animals. Using a single number to estimate digestive capacity of enzymes can obscure important differences among species in the locale and mode of nutrient digestion.

The membrane-bound hydrolases of cedar waxwings and thrushes correspond well with the nutrients in their natural diets. The extent to which the digestive traits of these frugivores influence diet selection will require nutritional studies that measure the utilization of nutrients from experimental diets that vary in nutrient type and concentration. For instance, the lack of sucrase precludes the utilization of sucrose, an abundant plant sugar, strongly influencing the preferences of birds for sucrose-rich foods (Martínez del Rio et al. 1988; Martínez del Rio and Stevens 1989; Martínez del Rio 1990; Malcarney et al. 1994). The ability of frugivorous birds to modulate the amounts and distributions of carbohydrases and aminopeptidase- $\mathrm{N}$ in response to diet composition is not well documented (see Afik et al. 1995). Passerine birds appear not to modulate disaccharidases to the nutritional composition of the diet, but dipeptidase activity often varies with the level of dietary protein (Afik et al. 1995; Karasov 1996; Sabat et al. 1998; but see Levey et al. 1999). Thus, for frugivorous passerines, results for aminopeptidase- $\mathrm{N}$ are likely to depend on the dietary regimen of experimental subjects. Because nutrient utilization is a complex process that is determined by a large suite of morphological and physiological traits (Alpers 1987), as well as interactions among dietary components, determining the functional limits to diet breadth of any particular trait will require detailed nutritional and physiological studies.

\section{Acknowledgments}

We thank Larry Carbone for assistance in arranging the use of surgery rooms at the Cornell University Veterinary Clinic. We are grateful to John Reiss and Richard Medville for help with animal surgery. This study benefited from the advice and support of Deedra McClearn, Peter Van Soest, and David Winkler. Debbie Phillips, Maria Vergara, and José Rios provided invaluable laboratory assistance. We thank Peter Brodfuehrer and two reviewers for their constructive comments on this article. This study was supported by the National Science Foundation (BIR-9509464 to M.C.W. and IBN-925805 to C.M.R.).

\section{Literature Cited}

Afik D., E. Caviedes-Vidal, C. Martínez del Rio, and W.H. Karasov. 1995. Dietary modulation of intestinal hydrolytic enzymes in yellow-rumped warblers. Am J Physiol 269: R413-R420.

Alpers D.H. 1987. Digestion and absorption of carbohydrates and proteins. Pp. 1469-1486 in L.R. Johnson, ed. Physiology of the Gastrointestinal Tract. Vol. 2. Raven, New York.

Anderson G.L. and E.J. Braun. 1985. Postrenal modification of urine in birds. Am J Physiol 248:R93-R98.

Bell G.P. 1990. Birds and mammals on an insect diet: a primer on composition analysis in relation to ecological energetics. Pp. 416-422 in M.L. Morrison, C.J. Ralph, and J.R. Jehl, eds. Avian Foraging: Theory, Methodology, and Applications. 
Studies in Avian Biology 13. Cooper Ornithological Society and Allen Press, Lawrence, Kans.

Biviano A.B., C. Martínez del Rio, and D.L. Phillips. 1993 Ontogenesis of intestine morphology and intestinal disaccharidases in chickens (Gallus gallus) fed contrasting purified diets. J Comp Physiol 163B:508-518.

Dahlqvist A. 1984. Assay of intestinal disaccharidases. Scand J Clin Lab Invest 44:69-172.

$\rightarrow$ Felsenstein J. 1985. Phylogenies and the comparative method. Am Nat 126:1-25.

$\rightarrow$ Garland T., Jr., and S.C. Adolph. 1994. Why not to do two species comparative studies: limitations on inferring adaptation. Physiol Zool 67:797-828.

Kania R.K., N.A. Santiago, and G.M. Gray. 1977. Intestinal surface amino-oligopeptidases. J Biol Chem 252:4929-4934.

Karasov W.H. 1996. Digestive plasticity in avian energetics anc feeding ecology. Pp. 61-84 in C. Carey, ed. Avian Energetics and Nutritional Ecology. Chapman \& Hall, New York.

Karasov W.H. and I.D. Hume. 1997. The vertebrate gastrointestinal system. Pp. 407-480 in W. Dantzler, ed. Comparative Physiology, vol. 1. Handbook of Comparative Physiology, sec. 13. Oxford University Press, New York.

$\rightarrow$ Karasov W.H. and D.J. Levey. 1990. Digestive system trade-offs and adaptations of frugivorous passerine birds. Physiol Zool 63:1248-1270.

$\rightarrow$ Levey D.J. and G.E. Duke. 1992. How do frugivores process fruit? gastrointestinal transit and glucose absorption in cedar waxwings (Bombycilla cedrorum). Auk 109:722-730.

$\rightarrow$ Levey D.J., A.R. Place, P.J. Rey, and C. Martínez del Rio. 1999 An experimental test of dietary enzyme modulation in pine warblers Dendroica pinus. Physiol Biochem Zool 72:576-587

$\rightarrow$ López-Calleja M.V. and F. Bozinovic. 2000. Energetics and nutritional ecology of small herbivorous birds. Rev Chil Hist Nat 73:411-420.

Malcarney H.L., C. Martínez del Rio, and V. Apanius. 1994. Sucrose intolerance in birds: simple nonlethal diagnostic methods and consequences for assimilation of complex car bohydrates. Auk 111:170-177.

Maroux S., D. Louvard, and J. Baratti. 1973. The aminopeptidase from hog intestinal brush-border. Biochim Biophys Acta 321:282-295.

Martin A.C., H.S. Zim, and A.L. Nelson. 1951. American Wild $\rightarrow$ life and Plants: A Guide to Wildlife Food Habits. Dover, New York.

$\rightarrow$ Martínez del Rio C. 1990. Dietary, phylogenetic, and ecological correlates of intestinal sucrase and maltase activity in birds. Physiol Zool 63:987-1011.

Martínez del Rio C., K.E. Brugger, J.L. Rios, M.E. Vergara, anc $\rightarrow$ M.C. Witmer. 1995. An experimental and comparative study of dietary modulation of intestinal enzymes in European starlings (Sturnus vulgaris). Physiol Zool 68:490-511.

Martínez del Rio C., W.H. Karasov, and D.J. Levey. 1989. Phys $\rightarrow$ iological basis and ecological consequences of sugar preferences in cedar waxwings. Auk 106:64-71.

Martínez del Rio C. and B.R. Stevens. 1989. Physiological constraint on feeding behavior: intestinal membrane disaccharidases of the starling. Science 243:794-796.

Martínez del Rio C., B.R. Stevens, D. Daneke, and P.T. Andreadis. 1988. Physiological correlates of preference and aversion for sugars in three species of birds. Physiol Zool 61: 222-229.

McLelland J. 1975. Aves: digestive system. Pp. 1857-1882 in R. Getty, ed. The Anatomy of Digestive Animals. Vol. 2. Saunders, Philadelphia.

$\rightarrow$ McWilliams S.R., E. Caviedes-Vidal, and W.H. Karasov. 1999. Digestive adjustments in cedar waxwings to high feeding rate. J Exp Zool 283:394-407.

$\rightarrow$ Meynard C., M.V. López-Calleja, and F. Bozinovic. 1999. Digestive enzymes of a small avian herbivore, the rufous-tailed plantcutter. Condor 101:904-907.

$\rightarrow$ Nichols B.L., J. Eldering, S. Avery, D. Hahn, A. Quaroni, and E. Sterchi. 1998. Human small intestinal maltase-glucoamylase cDNA cloning: homology to sucrase-isomaltase. J Biol Chem 273:3076-3081.

$\rightarrow$ Pappenheimer J.R. and K.Z. Reiss. 1987. Contribution of solvent drag through intercellular junctions to absorption of nutrients by the small intestine of the rat. J Membr Biol 100: 123-136.

Place A.R. 1992. Comparative aspects of lipid digestion and absorption: physiological correlates of wax ester digestion. Am J Physiol 263:R464-R471.

$\rightarrow$ Place A.R. and E.W. Stiles. 1992. Living off the wax of the land: bayberries and yellow-rumped warblers. Auk 109:334-345.

Prinzinger R., A. Presmar, and E. Schleucer. 1991. Body temperature in birds. Comp Biochem Physiol 99A:499-506.

Purvis A. and A. Rambaut. 1995. Comparative analysis by independent contrasts (CAIC): an Apple Macintosh application for analysing comparative data. Comput Appl Biosci 11: 247-251.

$\rightarrow$ Redford K.H. and J.G. Dorea. 1984. The nutritional value of invertebrates with emphasis on ants and termites as food for mammals. J Zool (Lond) 203:385-395.

Robbins C.T. 1993. Wildlife Feeding and Nutrition. 2d ed. Academic Press, New York.

Sabat P., F. Novoa, F. Bozinovic, and C. Martínez del Rio. 1998. Dietary flexibility and intestinal plasticity in birds: a field and laboratory study. Physiol Zool 71:226-236.

Sibley C.G. and J.E. Ahlquist. 1990. Phylogeny and Classification of Birds: A Study in Molecular Evolution. Yale University Press, New Haven, Conn.

Skadhauge E. 1982. A quantitative survey of salt and water excretion. Comp Biochem Physiol 71A:481-483.

Stevens C.E. 1988. Comparative Physiology of the Vertebrate Digestive System. Cambridge University Press, Cambridge.

$\rightarrow$ Thomas D.H. 1982. Salt and water excretion by birds: the lower 
intestine as an integrator of renal and intestinal excretion. Comp Biochem Physiol 71A:527-535.

$\rightarrow$ Wheelwright N.T. 1986. The diet of American robins: ar $\rightarrow$ analysis of U.S. Biological Survey records. Auk 103: 710-725. $\rightarrow$ Witmer M.C. 1996. Annual diet of cedar waxwings based or $\rightarrow$
U.S. Biological Survey records $(1885-1950)$ compared to diet of American robins: contrasts in dietary patterns and natural history. Auk 113:414-430.

1998. Ecological and evolutionary implications of energy and protein requirements of avian frugivores eating sugary diets. Physiol Zool 71:599-610.

Witmer M.C. and P.J. Van Soest. 1998. Contrasting digestive strategies of fruit-eating birds. Funct Ecol 12:728-741. 